\title{
Thinking Across the African Past: Interdisciplinarity and Early History
}

\author{
Kathryn M. de Luna • Jeffrey B. Fleisher • Susan Keech McIntosh
}

(C) Springer Science+Business Media, LLC 2012

\section{Introduction}

The contents of this special issue of African Archaeological Review stem from a conference convened at Rice University in March, 2011, "Thinking across the African Past: Archaeological, Linguistic and Genetic Research on Precolonial African History," and reflect a renewed interest in interdisciplinary approaches to the study of Africa's early past (Blench \& MacDonald 1999; Swanepoel et al. 2008; Stahl 2009, 2010; Stahl \& LaViolette 2009; Tishkoff et al. 2009; Delius \& Schoeman 2010; Mulaudzi et al. 2010; Pakendorf et al. 2011). The conference sought both to showcase new, explicitly interdisciplinary work on African history and to create an opportunity for dialog with scholars working on similar problems in Europe, Asia, and Latin America (see Appendix). Conference invitations charged the participants with two tasks. First, it was hoped that they would engage earlier criticism of attempts at correlating streams of historical data from different methodologies and even propose alternative means of connecting historical records. Yet, such new methodologies needed to respect the production and analysis of each form of evidence within disciplinespecific epistemologies. Second, it was assumed that the range of participants would allow debate to move past disciplinary gridlock by identifying how distinctive, discipline-specific knowledge can contribute to African historiography. Thus, the conference was convened to invigorate discussion of and beyond the confirmation paradigm, in which scholars seek out evidence from other historical disciplines to confirm the when and where of their own conclusions and, as a result of this limited interdisciplinary engagement, confine the interpretive step of historical reconstruction to the evidence from their own discipline (see also Robertshaw 2000).

The organization of the conference and composition of the panels were vital to meeting these goals. Prominent scholars in archaeology, linguistics, and genetics opened the conference with a series of comments on the state of research on early 
African history in their field and their own impressions of the misunderstandings nonspecialists have of their methodologies. These papers established a baseline "interdisciplinary literacy" and set the agenda for many of the debates that followed. Panels were composed of specialists engaging with each of three major forms of data - linguistic, archaeological, and genetic - and focused on particular regions within Africa. Each panel featured at least one scholar presenting new research paired with discussants from another discipline whose research overlapped in region or theme but not in methodology or data. By pairing scholars across disciplinary boundaries, the conference tried to shift the focus away from specific historical problems in order to foreground conversations on the limits and overlaps of historical datasets, as well as challenges for future interdisciplinary research and cross-methodological collaboration. Established scholars of ancient African and European history provided final commentary. By the close of the conference, participants had identified a number of questions and problems about both the potential methodological and theoretical contributions of current interdisciplinary research and its historiographical impact. We hope this special issue conveys the richness of the conference discussions. In this introduction, we outline a brief history of the relationship between archaeology and historical linguistics since the last historiographical overview (Vansina 1979, 1980) and share our own hopes for the role of genetics in African history. We also provide thoughts on persistent points of confusion, convergence, and disagreement that emerged during the conference.

\section{Archaeology and Historical Linguistics: A Shared Past}

Though there are many times and places where archaeological and historical linguistic data have been brought together, our discussion here focuses on work on the Bantu-speaking region. This focus results not only from our own research interests but also the long trajectory of research on the Bantu expansions (Vansina 1979, 1980). The sheer number and vast geographic expanse of the Bantu languages captured the imagination of early European travelers and scholars who saw in these events evidence of a history of conquest similar to their own recent past. As explanations of the distribution and size of the Bantu language group shifted from a racial understanding of the intellectual and military superiority of Bantu speakers to an expansion driven by technological superiority (following Childe's new explanations for change in European prehistory), a path opened for archaeologists to enter debates on the Bantu expansions. The 1960s and 1970s were the heyday of correlating archaeology and historical linguistics in African history (Soper 1971), culminating in the edited volume by Ehret and Posnansky (1982). Initially, linguists and historians using historical linguistic data studied the diffusion of Bantu languages in time and space as evidence of the diffusion of human populations across space. The application of the Words and Things approach opened the possibility of using linguistic evidence to track the diffusion of the activities of speakers, including developments in subsistence and technology, leading to a seemingly natural link with contemporaneous research in African archaeology (Vansina 1979, 1980). This was a time when efforts in archaeology, especially for the Iron Age, were aimed at creating spatiotemporal frameworks for the diffusion of populations and technologies based 
on artifact styles and distributions (Soper 1971; Phillipson 1977). In the Bantu Expansions project, archaeology and historical linguistics were brought together by the common goal of developing a chronological framework for the expansions by measuring, testing, relating, and then sequencing material culture and protolanguages. At a time when universalizing narratives of human prehistory served to support post-WWII anti-fascist political agendas in the historical disciplines, Bantu Expansions research integrated African achievements into world history using the themes dominating the universalist paradigm, such as the transition to agriculture and the development of sophisticated political and architectural forms (Klieman 2003; Stahl 2005). By the end of the 1970s, it seemed that much progress had been made on the timing and direction of the spread of "Bantu" people, languages, and technologies. Indeed, the future seemed bright: "From (the correlation of linguistic and archaeological data), a fuller and more satisfying early history of Africa can begin to be built" (Ehret \& Posnansky 1982: 1).

Critics, however, argued that work on the Bantu Expansions problem elided the complexity of local stories by foregrounding regional and continental similarities, patterns, and relationships across the broad Bantu domain and Iron Age horizon. What was lost, they argued, were stories embedded in the unique qualities of local ecology, material culture and language as reflected in ceramic distributions, semantic innovations, household layouts, and faunal collections (Lwanga-Lunyiigo 1976; Gramly 1978; Kuper \& van Leynseele 1978; Flight 1981; Robertson 1981; Hall 1990; Vansina 1994/1995, 1995a, b; Robertson \& Bradley 2000). These critiques inspired a trend of scaling down the geographical and temporal scope of research agendas that has persisted since the 1990s. Archaeologists took a more regional approach to social and political change and historians used the comparative method both to illuminate the history of speakers of subbranches of Bantu and to link those histories to later precolonial and colonial stories rooted in oral traditions and personal testimony (Schmidt 1978, 2006; McIntosh \& McIntosh 1980; Vansina 1990, 2004; Ehret 1998; Schoenbrun 1998; Kusimba 1999; McIntosh 1999; Horton \& Middleton 2000; Pikirayi 2001; Stahl 2001; Klieman 2003; Shetler 2007; Gonzales 2009; Stephens 2009, forthcoming; Saidi 2010).

Among many examples, two works stand out as both representative of and influential in this transformation, as archaeologists and historical linguists turned away from the "master narrative" and interdisciplinarity that characterized previous studies of the early history of Bantu-speaking regions. In archaeology, the rich diversity of regional approaches can be found in Shaw et al.'s (1993) volume, The Archaeology of Africa, a microcosm of current research as presented at the first World Archaeological Congress in 1986. Although the book highlighted regional projects, its overall structure was focused on a series of topics important in African archaeology, the subtitled "food, metals, and towns." The goal, it seems, was to begin writing complex regional narratives about these topics, which were broadly comparative in scope, situating the archaeology of Africa in terms of larger debates within archaeology itself. One topic not emphasized in the volume, but present in a number of the chapters (e.g., Collett 1993; Kense \& Okoro 1993; Rowlands \& Warnier 1993), was ethnoarchaeology. This subfield blossomed in Africa in the 1980s, providing ethnographic models of material culture use that could be applied to the archaeological record (Hodder 1982; Schmidt 1983). However, like the topics of urbanism or food 
and craft production, early ethnoarchaeology in Africa was aimed primarily at broader theoretical concerns, even while local histories were drawn out (Hodder 1982; Herbich 1987; Dietler \& Herbich 1989; see also David \& Kramer 2001). For example, ethnoarchaeology was crucial to the symbolic interpretations of both iron production in the Early Iron Age (Schmidt 1978) and the use of pottery (David et al. 1988).

The Archaeology of Africa volume did include chapters on linguistic data describing both the large-scale classifications that divided the continent (Blench 1993a, b; Ehret 1993), as well as linguistic evidence for the ancient use of animals (Blench 1993a, b) and plants (Williamson 1993). Only a few regional studies used both linguistic and archaeological evidence (Eggert 1993; Kiriama 1993; Phillipson 1993). Both Kiriama and Eggert were critical of correlating linguistic data with archaeology, suggesting that the extensive knowledge of Bantu linguistics trumped that of archaeology; thus, the richness of linguistic information was not easily "transposed" (Eggert 1993: 327) to archaeological interpretations. They argued that renewed archaeological field work was required in many neglected regions to offer a more firm empirical footing for reconstructing the past. Phillipson (1993), however, used linguistics to help confirm and expand upon archaeological data; this was in line with his previous work seeking to correlate or "supplement" archaeological data, especially in the elucidation of the Bantu expansions (Phillipson 1977, 1985). This important volume, therefore, continued to recognize the prospects for integrating archaeological and linguistic data but demonstrated that this work was occurring adjacently, without much consideration of how these data might be drawn together for historical interpretations. Questions propelling regional research, ethnoarchaeology, and an emerging emphasis on symbolic approaches seemed to further distance archaeologists from an older project emphasizing culture history, archaeological stages, and correlated language history.

This archaeological work can be contrasted with Jan Vansina's contemporaneous research on equatorial history, published as Paths in the Rainforests (1990). Vansina used reconstructed word histories to write a regional political history for central Africa. With his focus on a smaller region and use of the Words and Things approach, Vansina transformed the historical value of data produced by the comparative historical linguistic method, from evidence for the historical development and diffusion of languages and technologies into evidence for regional social history. Vansina was one of the first to propose a historical methodology, what he called "upstreaming," to link linguistic, ethnographic, and where available, archaeological evidence, working back from the present, from the known to the unknown (Vansina 1990: 31-33). Although Vansina tried to integrate archaeology (e.g., Vansina 1990: 102-104), the equatorial region was poorly known. He therefore described a possible future for archaeological research based on historical linguistic reconstruction as a means of testing the hypotheses derived through language reconstructions, a classic iteration of the test and confirm paradigm (Vansina 1990: 250).

Working at the regional scale seems to have influenced Vansina's expectations for the engagement between archaeology and linguistics. It may have been the experience of writing Paths in the Rainforests and the revelation that deep history could be written as social history that led Vansina to critique archaeologists (1995), suggesting that they were too concerned with stages and evolutionary trajectories and, as a result, 
were pursuing ahistorical questions. If many archaeologists were puzzled by Vansina's critiques of African archaeology, it was because this conversation was already underway in specialist journals where Africanist archaeologists explored the discipline's relationship with oral traditions, ethnography, and symbolism (e.g., Schmidt 1983). Though some of this work predated Vansina's critique (especially work on oral traditions and ethnoarchaeology), these trends were firmly established in archaeology during the 1990s. The ensuing public debate (Robertshaw 2000) further distanced two fields that were, in retrospect, beginning to share a concern with social life that might have led earlier to a more robust interdisciplinary engagement.

Recently, Richard Reid (2011) has lamented the more general marginalization of precolonial history in Africa, arguing that the diminishing number of precolonial studies has served to detach Africa's early and later histories. While many specialists in early African history share a concern with the temporal disconnect that Reid observes, the position of early African pasts in the study of the continent is also a disciplinary issue. Rather than simply a regard for diverse sources (Reid 2011: 138, 153), discussion and engagement must occur between the disciplines in order to examine the relationship between different methodologies, the data they create, and the historical contexts they elucidate and-importantly-might connect.

\section{Persistent Challenges}

Both archaeology and historical linguistics employ sophisticated methods for producing data. So, it is, of course, important for historically-minded researchers to understand multiple data-producing methodologies in order to assess the quality of the production of particular forms of evidence, and their limitations (Vansina 2009: 430-431). Those proposing to work with data produced in a discipline not their own, therefore, must have some basic grasp of field and analytic methods, all the more so when seeking to use one historical record to confirm another. Once data have been produced, two challenges plague the would-be interdisciplinary researcher. First, there is the determination of which regional linguistic and archaeological records to compare, and whether or how to align their narratives when the temporal and spatial scales represented by the data are so vastly incongruent. Second, there are questions that different forms of evidence invite about past social life and the specific ways such evidence is interpreted to elucidate past social practice. It is this second challenge that propels us past the confirmation paradigm to a dynamic dialog between historical records.

\section{Scale, Context, and Subjects}

In scaling down their research contexts (e.g., subbranches within Bantu, and regional or even site-specific patterns within archaeology) to better engage with debates in their respective disciplines and the social sciences more generally, archaeologists and historical linguists have actually come to focus on a number of shared interests such as identity politics, political authority, and ritual practice, all rooted in a shared concern for social life. However, scale remains a challenge as scholars struggle to link the data representing very different spatial and temporal extents and exploit the 
distinctive questions that can be both conceived and answered with particular forms of data. If scale was once a means of critiquing poor efforts at correlation, it now would appear to be a problem in its own right.

Scale itself, as a basis for correspondence, serves as the argument by which some scholars link the archaeological and linguistic record (Phillipson 1993; Ehret 1998, 2000; Schoenbrun 1998; Klieman 2003; Gonzales 2009). However, the study of thematic problems and social history offers alternative methods for connecting historical records. For example, the simple overlap in space of evidence for a shared feature of the two records, such as the emergence of cattle-keeping or metallurgy, justifies Vansina's method of direct association, a novel approach at linking the archeological and linguistic records in order to date proto-languages (Vansina 2004; see also de Luna 2012). This overlap is clearly determined for archaeological data by the location of excavated material culture and decidedly less so for the location of ancient speech communities using reconstructed proto-forms, but it has been nonetheless compelling. As MacEachern (2012) shows, the different scalar qualities of archaeological, linguistic, and genetic data can be used productively as a way to challenge models and interpretations developed by relying on only one record. In some research areas, there has been a useful coming together of archaeological and historical linguistic research at the regional scale, such as in the Great Lakes or on the Swahili coast (Nurse and Spear 1985; Schoenbrun 1998; Robertshaw 1999, 2010). In these cases, there is no effort to justify the connection between the datasets since the extent of research carried out offers relative confidence in connecting them. Yet, the scales represented by our evidence do not align equally in all regions; this is a challenge for both the academic task of connecting independent historical records as well as the humanistic imperative to understand the meaningful scales of our subjects: buried and mourned individuals, speech communities, residents of a compound, kingly courts, multilingual speakers, urban neighbors, or initiates competent in the restricted lexicon of an itinerant healing cult.

Particular disciplines and specific methodologies "see" from different scalar points of view, shaping how scholars weave together narrative strands into reconstructions of particular communities, events, and processes. For example, historical linguistics as a methodology cannot produce evidence to tell a story about the speakers of one village as archaeology might for the inhabitants of a single settlement or even a single residence (e.g., Stahl 2001). Though problems in sociolinguistics can be studied within such a narrow spatial framework, the data of historical linguistics come from a spatial and temporal scale that far surpasses the village or town. For historical linguistics, the advantage of archaeology, then, is not only the direct testimony of the evidence unmediated by the experience of later generations - the artifact or feature produced by the subjects of the story-but also its hyper-local nature, its spatial rootedness (see Fleisher \& Wynne-Jones 2012). This can occur, however, only where a regional archaeological framework has been established, something that is lacking in many parts of the continent. It is only through the hard work of building up regional sequences of material culture patterns and chronologies that archaeologists can begin to explore the most local contexts, such as a village or house. Where this is possible, archaeologists' historical interpretations can help historical linguists scale down to local, even individual, experiences. For archaeologists, linguistic evidence provides an alternative path to scaling up, a path that might or might not correspond 
to the patterns emerging from survey work or regional ceramic analysis and could extend well beyond the bounds of time and space represented by archaeological data (see MacEachern 2012).

\section{Ethnography and Disciplinary Approaches to Social Life}

Even as scholars engage with the unique possibilities of the scales of our different evidence and propose new methodologies to bridge those scales, they do so to better engage with our common interests in social life. Ethnography constitutes a bridge between the objects of study - words, genes, and things - and what they reveal about the lives and ideas of Africans living long ago. Though ethnography looms large in the reconstruction of early African history, its use varies widely between disciplines and a simple but often overlooked question remains: what impact do the different disciplinary practices for using ethnography have on the project of interdisciplinary scholarship on early African history?

By the 1990s, both archaeologists and historians using linguistic evidence understood ethnography to have a central place in the reconstruction of early African history, but there were significant differences between their approaches. Historians use ethnographic data in a comparative manner that mirrors their comparative approach to language, focusing on communities that speak the descendent languages of the proto-languages spoken by the subjects of their research (Sapir [1916] 1985; Vansina 1990; Schoenbrun 1998). The goal is to assemble complexes of associated items and ideas whose relationship is supported by redundancies in ethnographic descriptions of their use by linguistically related communities. They are also supported by the multiple meanings and derivational paths revealing words' semantic histories and, therefore, the discursive means by which speakers created such associations. The historicity of complexes revealed through the comparative ethnographic method, when supported by the independent linguistic record, adds depth to our understanding of the social context in which words, practices, and objects were made meaningful at different moments in the deep past. As Schoenbrun (1998: 266) describes, the strength of the "historian's case" rests on scouring the regional ethnographic record to find multiple examples of "which ideas and things are associated in practice," then exploring the "distributions and meanings for each one of those associated ideas and things" in the independent ethnographic and linguistic records and, finally, contextualizing each "idea and thing" with others in the "ethnographic and linguistic record."

Archaeologists deploy a similar process, through ethnographic and direct historical data and ethnoarchaeological research (Steward 1942; Stahl 1994; Schmidt \& Mapunda 1997). One distinction, however, is that archaeologists also utilize ethnographic analogies without historical connections to the context under study (what Ascher 1961 called "new analogy;" see also Wylie 1985; Stahl 1993) but which share "boundary conditions," such as similar environmental or political settings. There has been much debate about the appropriateness of such ethnographic analogies, especially when they have served to freeze a particular cultural form as normative, which is then read onto archaeological data. For example, in the case of the Kalahari, there has been much criticism of how rich ethnographic studies of hunter gatherers in the 1960s and 1970s served to obscure variable and complex subsistence practices in the 
past, both in the Kalahari itself and beyond (Schrire 1980; Wilmsen \& Denbow 1990). Stahl (1993, 2001) urged archaeologists to carefully evaluate all analogies, subjecting them to both source- and subject-side criticism as a way of avoiding the potential pitfalls of reading the present back into the past. Common to these approaches is the use of "diverse sources ... comparatively, tacking back and forth between present and past to understand change and continuity in local life" (Stahl 2001: 28; Wylie 1985). In general, linguists, when they use ethnographic data, tend to follow the direct historical and new analogy approaches of archaeologists rather than the comparative ethnographic approach to complexes advocated by historians (e.g., Marck \& Bostoen 2011 on the early history of kinship compared with Stephens 2009 on lineality in North Nyanza). This may be a result of the tendency among linguists to reconstruct vocabulary across the entire Bantu domain or much broader portions of it (but see Nurse \& Hinnebusch 1993; Bostoen 2007).

We think these similarities and differences in the use of ethnography are important because they speak to the disciplinary concerns that shape our research agendas. In the case of archaeology, the use of "new analogy" illuminates the thematic and theoretical framing of disciplinary interventions (in urbanism, food production, representation, and other cross-regional and comparative historical processes), though archaeologists are certainly concerned with the historical experiences of the makers of the material culture they study! Likewise, it is worth stating for nonspecialists that although both historians and linguists apply the comparative historical linguistic method (and thus use starred forms), they often write with quite different subjects and goals even if they share historical topics (such as developments in how people feed themselves or reckon kinship relations). Historians seeking to engage with colleagues in their discipline tell stories in which people and communities of speakers are the agents, while linguists might write about the development of languages, words, or technologies without focusing primarily on human agency or historical contingency. Indeed, for many linguists, it would be unthinkable to posit a testable, knowable semantic history of words for many of the domains of life that most interest Africanist historians who use linguistic data, such as lexicons of justice, political ideology, ritual, kinship, and affect (see Vansina 2009: 428-430 on linguists' "certainties" and historians' "probabilities"). Linguists working on early African history make vital contributions to our understanding of the history of subsistence, metallurgy, pottery, and other crucial domains of concrete, material life (though not exclusively so; e.g., Marck \& Bostoen 2011), in addition to providing important narratives of linguistic and population diffusion and evidence of the historical development of the languages themselves. This follows more closely the European tradition of the Words and Things approach in which linguists' contribution to the reconstruction of early history was to search out linguistic evidence for aspects of life that could be linked to the material cultural sequences recovered by archaeologists. These differences are worthy of the attention of archaeologists pondering the linguistic record of their region of specialty because, as Vansina (2009) notes, historians are more comfortable producing less certain, less testable semantic histories in order to reach into ancient social life (consider also Fleisher \& Wynne-Jones 2012).

Historians and linguists interested in the production of evidence for non-material aspects of life in early African communities also have much to learn from how archaeologists think about the relationship between ideational and material life, with 
its growing attention to the distinction between materialization and materiality (Robertshaw 2012). Historians often recognize the way material objects (or spaces) can reflect or represent social developments and ideological positions; for example, the construction of a palace or central space where access was controlled by particular individuals is easily understood as the "materialization" of a form of power. Studies of materialization often focus on relations of power and inequality (DeMarrais et al. 1996), but other archaeologists have examined the way cosmology (Lucero 2010), ritual (Insoll 2009), performance (Inomata \& Coben 2006), or communities are materialized through material culture practice. Although this understanding of the representational qualities of material culture is a significant advance over purely functional understandings of objects, it tends to overlook the role that objects play in constituting culture and human relations (Miller 2005). The concept of materiality suggests that objects and settings were active, and had a social role rather than simply reflecting social truths. Thus, even the most mundane objects, through their production and use (as well as their durability) can be understood as playing a role in constituting cultural and social life. As Meskell (2005: 4) notes about the object world: "their residual force of matter has the ability to shape and influence the living." This allows for the material culture of the archaeological record to be considered as a dynamic part of a contingent history. It also reinvigorates the production of reconstructed lexicons of seemingly banal material culture, for the light such lexicons may shed on the social and cultural life of speakers of proto-languages (de Luna 2012).

\section{The Potential of Genetics}

While intersections of archaeology and linguistics in Africa have a long, if uneven, history of fairly direct engagement, genetics and archaeology have been more distant partners. From the 1950 s to early 1990 s, genetic studies were primarily directed at classic protein polymorphisms, such as blood types and hemoglobin variants, and captured information on genetic variation indirectly via phenotypes. Understanding the inheritance patterns and the distribution of genetic variants provided important information on disease susceptibility and medical treatment. For example, the discovery that certain hemoglobin variants were under selective pressure due to the protection from malaria that they conferred, drove a considerable amount of genetic research in the 1970s and 1980s (Excoffier et al. 1987). The archaeological link to positive selection for the sickle cell trait was made by Livingstone (1957), who proposed that the shift from hunting/gathering to slash-and-burn agriculture in the forest margins created breeding sites for mosquito vectors as well as larger and more settled human host populations for transmission of the malaria parasite. More influential for archaeology was the collaboration of Albert Ammerman, a European archaeologist, and Cavalli-Sforza, a geneticist, who proposed that the observed clinal patterning of genetic variation in Europe reflected a colonizing wave of advance by farmers from the Near East (Ammerman \& Cavalli-Sforza 1984). The publication in 1994 of The History and Geography of Human Genes (Cavalli-Sforza et al. 1994) confirmed the power of genetic analysis to illuminate historical process. Viewed within an evolutionary framework, genetic variation is always an historical process that develops over time as a result of the differential and contingent operation of just 
four factors: natural selection, gene flow (migration and intermarriage, preferential mating), mutation, and random factors (genetic drift). However, for researchers interested in population histories and genetic relationships, the classic polymorphisms had the disadvantage of being subject to natural selection, which can produce similar gene frequencies as a function of similar environmental conditions rather than historical affinity.

The discovery in the early 1980s of a sector of mitochondrial DNA that did not code for any genes and accumulated mutations without exposing them to selection was, therefore, a game changer. Even better, mtDNA is passed down intact from mother to child (unlike autosomal DNA, bits of which are shuffled between homologous parental chromosome strands during recombination), making the identification of historical maternal lineages fairly straightforward. Since then, direct investigation of mtDNA sequences, and subsequently $\mathrm{Y}$ chromosome sequences, has become an increasingly prevalent and powerful way to document human population genetic variability. Early publications considered patterns at only the broadest scale-e.g., the "mitochondrial Eve" paper that outlined the sequence of lineage differentiation and population movements by modern humans after leaving Africa (Cann et al. 1987). From the outset, these studies attracted criticism regarding the quality and representativeness of the samples and the reliability of the molecular clock used to estimate the age of the various lineages (Excoffier et al. 1987).

Technological advances have resolved some of these early problems: polymerase chain reaction (PCR) has solved the problem of getting enough DNA for sequencing by amplifying the small amounts in a blood or saliva sample billions of times. Greater precision has recently been achieved with the human mitochondrial molecular clock (Soares et al. 2010), but the time estimates for the emergence of new lineages still range over thousands of years. Concerns remain over samples of unknown/undeclared origin and relationship, as well as the small sample sizes from individual populations and the very uneven geographic coverage of the available samples. These problems contribute to the very coarse resolution of the genetic data for population history. Other critical factors have been the relatively small number of genetic markers (mutation sites) that were initially identified as significant and the technological challenges of identifying and sequencing the larger numbers of markers needed for finer-grained resolution. With the advent in the last few years of automated, high-throughput sequencing, these difficulties have receded. Adding additional sites of variability on the mtDNA and Y chromosome has increased the recognition of sublineages and sub-sublineages, with correspondingly greater temporal and geographic resolution. New technologies have also made sequencing of the far vaster amount of autosomal DNA possible, which provides a more comprehensive perspective.

The coarse scale of much African genetic analysis to date can thus be understood as an artifact of technological limitations and inadequate sampling that are not unexpected at an early stage of a developing discipline. Looking at other regions of the world, we can see how debates over initial genetic claims, plus improvements in method and sample adequacy (which remains a persistent problem in much of Africa), have resulted in a productive feedback loop with archaeologists. The initial identification of macroscale genetic patterns attributed to the spread of farming populations in Europe, for example, prompted an intense dialogue between 
archaeology and genetics, leading to increasing improvements in genetic sampling and analysis, as well as new theorizing about an immensely well-developed archaeological database for early farming communities and contemporaneous hunter-gatherers. An initial proposal that the spread of the Neolithic in Europe was a relatively unitary phenomenon involving the steady demic expansion of Near Eastern populations with pottery and food production, was countered by those who believed that the novel cultural and technological elements spread mainly through cultural contacts involving little migration. This debate stimulated more genetic studies, new critiques, and the addition of paleogenetic studies of DNA from both Neolithic and huntergatherer human remains dated to the period 5500-2500 cal BCE. We now know that the process of Neolithization was vastly more complex, involving colonization by farmers in a leapfrog fashion, local adoption of farming by hunter-gatherers via contacts with colonizers, gene replacement that favored the indigenous huntergatherers, and a significant amount of local variation in these processes (the forgoing summarizes a number of points in Deguilloux et al. 2012). In Europe, the interaction of archaeology, genetics, and paleogenetics has produced results at the mesoscale, where regional and in some cases local patterns can be detected.

A similar state of affairs developed with regard to Oceania, as the case study by Scheinfeldt (McIntosh \& Scheinfeldt 2012) attests. The either/or proposition of Lapita as a Neolithic package introduced to Polynesia by seafarers from Taiwan or colonists from Melanesia was refuted by genetic analysis. This refocused the debate about Lapita origins on more complex explanations and new ways of theorizing, that moved beyond elite dominance models and farming/language dispersal models (Spriggs 2011: 523). The tight chronology for the spread of Lapita enables mesoscale analysis with a focus on processes of change that occurred over a period of a dozen or so human generations beginning 3,000 years ago.

How effectively genetic analysis (or archaeology for that matter) will operate at the microscale remains to be seen. For the historian, the microscale involves the individual agent and l'histoire evenementielle. Genetics can answer tightly focused questions about individuals and events - but only by reference to the lineages and population histories that the individuals embody and share with others. For the population geneticist, the microscale involves a narrowing of the frame of investigation to the level of neighboring populations combined with intrapopulation studies to investigate events that happened within a quite recent timescale (a few generations back from the present). Veeramah et al. (2008), for example, investigated the oral history claim that the ruling dynasty among the Nso in the Cameroon Grassfields traces its descent from a founding ancestress that married into a group of autochthonous hunter-gatherers. He found that the distribution of NRY and mtDNA haplotypes among the general Nso population compared with the ruling dynasty is consistent with this claim. This illustrates "the power of genetic anthropology to confirm the genetic consequences of social practices and labels" (Veeramah et al. 2008). Reversing the process to identify social practices from genetic patterns is far more challenging, however, since any given pattern might be the outcome of a variety of possible factors.

Current macroscale approaches in Africa follow a familiar pattern of linking lowresolution patterns of genetic similarities to certain "push" events presumed to be associated with demic expansions: food production (including pastoralism) and 
climate shifts. As these are often conceived of as unitary phenomena linked to the spread of particular language groups (Nilo-Saharan aquatic-oriented populations after the Last Glacial Maximum; Chadic and Cushitic-speaking pastoralists in the midHolocene; Bantu-speaking farmers and herders more recently), we can expect that improved resolution of both genetic and archaeological data will reveal a more complex picture, as it has in Europe and Oceania. Hints of this have begun to emerge (e.g., Pakendorf et al. 2011); because archaeology has greater potential temporal precision than either linguistics or genetics, high-quality archaeological data are essential to this agenda. This means many more well-dated archaeological assemblages from closed contexts than we currently have in most areas of Africa. Linguists, for their part, must strive for better "stratigraphies" of language change and seriated lexical evidence (Ehret 2012). For genetic analysis, moving from macro- to mesoscale investigations at a regional and subregional scale requires not only a greater quantity of samples from a greater number of populations but better sampling protocols. In addition to sampling underrepresented populations and geographic areas, researchers need to collect historical data on recent family histories, migration, and intermarriage among ethnolinguistic groups (Keita 2005), in order to avoid a facile equation of ethnolinguistic and genetic identity. Analyses that first characterize and then compare genetic variation according to population group depend on meaningful delineations of the populations sampled (MacEachern 2000). Newer analyses, such as STRUCTURE, avoid this problem, since they search for structure within the full range of samples collected, without defining populations ahead of time.

Given the vast physical extent of Africa and the extreme population diversity and genetic variability that it encompasses, it is a challenge to adequately characterize genetic variability within any given region. Time and continued effort will bring us closer to that goal. However, the extent to which inferences from modern populations about the past genetic variation are correct can only be assessed by studies of ancient DNA. Despite its acknowledged limitations, paleogenetics has been enormously influential in shaping the debates about Neolithization processes in Europe and investigating hypotheses about population continuity vs. discontinuity (Soares et al. 2010; DeGuilloux et al. 2012). By contrast, paleogenetics is still rare in Africa outside of Egypt. For those parts of the African continent where ancient DNA might be sufficiently well-preserved, collaborative archaeology-paleogenetic research programs must be encouraged and funded.

\section{Thinking Across the African Past: Contributions to an Interdisciplinary Dialog}

Contributors to this issue present a range of opinions on the state of interdisciplinary research on Africa's deep past and pressing concerns for future research. Disciplinary overviews by Robertshaw (2012), Ehret (2012), and McIntosh and Scheinfeldt (2012) collectively outline the stakes in undertaking interdisciplinary research by highlighting the misunderstandings, frustrations, and pitfalls involved. If, to use Wyatt MacGaffey's (1978: 103) observation, "African Historiography (has become) the decathlon of social science," how do we ensure methodological stringency and accuracy, much less the scholastic responsibility to keep up with literatures and the professional requirements to secure funding and acquire tenure within a discipline? 
Yet, these overviews share much hope for the potential of collaboration and the possibility of interdisciplinary literacy. Robertshaw (2012) traces the development of African archaeology and argues for a shift in the questions we share across disciplines: from the "when" and "where" questions that require correlating heuristic units of analysis to "how" questions that can be investigated independently on a region-byregion basis. He explores the potential of such a shift with a case study from the Great Lakes region. In the next overview piece, Ehret (2012) clearly explains what nonspecialists should expect of linguistic reconstructions. While the comparative historical linguistic method requires three broad steps (the assessment of historical relationships between languages, the diachronic reconstruction of the phonological systems, and the reconstruction of individual words and their meanings), the first and third steps, with their tree diagrams and starred forms, receive far more attention (and debate) from non-specialists than the second step. In carefully describing phonological analysis, Ehret demonstrates that nonspecialists have both the capacity and responsibility to assess the reliability of reconstructions proposed by historians and linguists. In the last overview, McIntosh and Scheinfeldt (2012) explore the potential contribution of genetic data to debates framed by linguistic and archaeological research in case studies of the settlement of remote Oceania and the historical origins of West African, particularly Fulbe, pastoralist communities. They are careful to point out the challenges of early genetic research in Africa and the ways in which the field is rapidly transforming to engage more nuanced problems in historical demography. In the West African case study, they keep multiple interpretations in play while outlining research agendas for archaeological, linguistic, and genetic research on the regional history of pastoralism, migration, and identity.

The four research papers that follow each take a unique path in exploring the relationships between historical evidence produced by archaeology, historical linguistics, and genetics. Fleisher and Wynne-Jones (2012) consider how the archaeological and linguistic records of the Swahili coast can be brought together to investigate historically contingent interpretations of space and daily practice. By working between fine-grained archaeological data from Songo Mnara, Tanzania and reconstructed words from published linguistic work, they attempt to draw out possible meanings and uses of public and private spaces, including the bounding and definition of public space, the linkage between commemoration and ancestry, and the variable uses and meanings of the house. By exposing the way that spatial practices and material deposits may have been meaningful acts in the past, they argue that material culture as represented in both archaeological and linguistic evidence needs to be considered as a dynamic part of a contingent history, rather than merely representations of past functions.

For de Luna (2012), regional parallels and correlations of units of analysis are poor methods for linking the linguistic and archaeological records of South Central Africa. Rather, she uses a method of associating the records directly by seeking both geographical and chronological overlaps in evidence for more specific, localized historical transformations. The latter include the emergence of communal hunting practices and delayed adoptions of intensive cattle-keeping, rather than the initial appearance of continent-wide transformations like metallurgy or cereal farming. de Luna argues that this method offers the potential to create more sophisticated interdisciplinary histories sensitive to the unique capacities of different forms of 
evidence to illuminate practice, agency, and contingency in regional histories of subsistence.

MacEachern (2012) considers the parallels and contradictions in the archaeological, linguistic, and genetic evidence for the settlement and subsistence economies of the Lake Chad Basin. The different scales reflected by particular forms of evidence may be productively exploited. For example, linguistic and genetic evidence for eastwest interactions challenges archaeologists' emphasis on the importance of northsouth interactions between Saharan and sub-Saharan areas. Similarly, archaeologists' access to direct evidence from the past in more certain spatial and temporal contexts constrains the more generalizing historical arguments developed from linguists' and geneticists' indirect, spatially vague evidence.

Blench (2012) scales down through two case studies the central problem of the Bantu Expansions: how languages and people spread. The Bantu Expansions phenomenon has generally been understood as a terrestrial one. Nonetheless, parallels between archaeological evidence of maritime material cultures on the one hand, and linguistic evidence of Bantu speakers' capacity to exploit coastal resources on the Atlantic coast and participate in long-distance, sea-faring trade networks on the Swahili coast, on the other, support Blench's hypothesis: that sea voyages may have played a greater role than previously thought in the diffusion of Bantu languages and populations. Blench draws a parallel with the Pacific coast of Mesoamerica and South America to query the historical durability of the different spatial forms (linear and network) of maritime cultures.

Two of the four research papers illustrate one of the current challenges to interdisciplinary research: few regions boast an historical linguist, archaeologist, and geneticist with active research projects. For example, Fleisher and Wynne-Jones' (2012) work on the Swahili coast relies on the published reconstructed terms in Nurse and Hinnebusch (1993), few of which reflect Fleisher and Wynne-Jones' interests in spatial practice. Similarly, de Luna (2012) relies on published archaeological reports, most of which are from the 1960s and 1970s and reflect that era's interest in culture history rather than archaeologists' more recent interest in social life. In each case, the complementary record is not well (or at all) connected to the ethnographic record so authors use their own evidence alongside the ethnographic record to inflect social dynamism into the historical reconstructions. But this is a sorry state of affairs, for it perpetuates the practice of relegating the evidence of other disciplines to a confirmatory role or interpreting it in a "safe" but instrumental manner. MacEachern's (2012) paper supplies an antidote, exploring the potential of comparing settlement narratives across the surprisingly rich archaeological, ethnographic, linguistic, and genetic records of the Lake Chad Basin. While the importance of social life may well breathe new life into efforts at interdisciplinary research and collaboration, Schoenbrun's (2012) final, critical commentary reminds us that the different disciplines justify their work within disciplinary parameters. Schoenbrun explores the narrative capacity of our different data and argues that it is the shared concern with human agency best expressed in narrative form that serves as the meeting place of our interdisciplinary efforts.

We hope this special issue of the African Archaeological Review inspires both interdisciplinary literacy and collaboration. As specialists in early African history, we are assured that our common thematic interests will continue to facilitate an approach 
to what happened in the past that transcends disciplinary boundaries. However, we are concerned that our dialogs continue around methodological and theoretical problems as well. Methodological debates about how to draw together different historical records are not dead just because we have recognized that correlating units of analysis is problematic. We think that theoretical advances in different disciplines ought to be discussed more by specialists in early African history for the payoff they provide to our colleagues in other fields. For example, historians benefitted tremendously from the emergence of sociolinguists' research on the relationship between social relations and speech. Likewise, linguists and historians are poised to benefit from post-processualist archaeologists' understanding of the distinction between materialization and materiality.

The papers in this special issue do not resolve the challenges at hand or even define the path forward. At the 30-year anniversary of the publication of The Archaeological and Linguistic Reconstruction of African History, we cannot present a state of the art as Ehret and Posnansky (1982) attempted with their comprehensive, region-by-region alignment of records. Yet, we are confident that future interdisciplinary scholarship will accomplish more than correlation or sifting through each other's work for useful evidence and conclusions. We can imagine collaborations, like that of Ehret and Posnansky, which move beyond a meeting place defined by common research topics, to new research that asks questions that can only be posited because they are framed on the basis of the methods and theoretical positions of multiple disciplines.

Acknowledgments The conference at Rice University would not have been possible without the financial and logistic support of the Humanities Research Center; in particular, we thank Melissa Bailar, Lauren Kleinschmidt, Carolyn Adams, Lorena Gauthereau, and Babatunde Babalola for crucial assistance with the conference itself. We benefited from the insightful comments of conference presenters and discussants: David Anthony, Koen Bostoen, Jim Denbow, Chap Kusimba, Derek Nurse, Brigitte Pakendorf, Thomas Spear, and Krishna Veeramah, in addition to contributors to this volume. We also appreciate the financial assistance of the Schools of Social Sciences and Humanities and the Department of History. Finally, we thank Adria LaViolette, who provided crucial support in preparing this issue.

\section{Appendix: Conference Schedule}

Thinking across the African Past: Archaeological, Linguistic, and Genetic Research on Precolonial African History

Friday, March 11, 2011

Panel 1: Remembering the Debates and Revisiting the Nature of Data

Maps upon Maps, Christopher Ehret (Professor of History, University of California, Los Angeles)

Old Stuff: African Archaeology, Multi-disciplinary Reconstructions of African's Past, and Archaeology's Role in Future Collaborative Research, Peter Robertshaw (Professor of Anthropology, California State University, San Bernadino)

Genetic Diversity: An Additional Screwdriver in the Historical Scholar's Toolbox, Krishna Veeramah (Postdoctoral Fellow, University of California, Los Angeles) 
Panel 2: West Africa: Interdisciplinary Intersections

History from the grave: integrating modern and ancient DNA studies with archaeological data in West Africa, Susan McIntosh (Professor of Anthropology, Rice University)

Explorations in early Bantu maritime history on the West Coast of Africa, Roger Blench (Independent Scholar and Affiliate of the Kay Williamson Educational Foundation)

DISCUSSANT: Scott MacEachern (Professor of Anthropology, Bowdoin College)

Saturday, March 12, 2011

Panel 3: Population Movement and Frontiers in South Central Africa

Surveying the Boundaries of History and Archaeology: Early Settlement in South Central Africa and the 'Sibling Disciplines' Debate, Kathryn de Luna (Assistant Professor of History, Rice University)

Bantu-Khoisan Contact in Southwestern Zambia: Gaining Deeper Insights into Sociocultural Processes of Language Contact through Interdisciplinary Research, Koen Bostoen (Post-Doctoral Researcher, Service of Linguistics, Research Institute, Musée Royal de l'Afrique Centrale) and Brigitte Pakendorf (Leader of the Independent Max Planck Research Group on Comparative Population Linguistics, Max Planck Institute for Evolutionary Anthropology)

DISCUSSANT: Jim Denbow (Associate Professor of Anthropology, University of Texas at Austin)

Panel 4: Reexamining the 'Reconstructed' Swahili: New Perspectives on Origins and Town Development

Words and Places: First Efforts on a History of Spatial Conceptions on the Ancient Swahili Coast, Jeffrey Fleisher (Assistant Professor of Anthropology, Rice University)

Decoding the Swahili: An Integrated Archaeological and Genetic Study of the Swahili of East Africa, Chapurukha Kusimba (Professor, Department of Anthropology, The Field Museum (with Sloan Williams, Janet Monge, Mohamed Mchulla, and Ryan Raaums)

DISCUSSANT 1: Derek Nurse (Professor Emeritus, Memorial University of Newfoundland)

DISCUSSANT 2: Thomas Spear (Professor Emeritus, University of Wisconsin at Madison)

Panel 5: Perspectives from Beyond the Continent

Correlating Language Borders with Prehistoric Material-Culture Borders: Yes We Can, David Anthony (Professor of Anthropology, Hartwick College)

Integrating Genetic Data with Archaeological and Linguistic Data in the Study of Past Population Histories, Laura Scheinfeldt (Research Scientist, Department of Genetics, University of Pennsylvania) 
Prehistoric population contact and language change in Siberia: An interdisciplinary perspective, Brigitte Pakendorf (Leader of the Independent Max Planck Research Group on Comparative Population Linguistics, Max Planck Institute for Evolutionary Anthropology)

Concluding Discussion: (4:00-5:30) David Schoenbrun (Professor of History, Northwestern University)

\section{References}

Ammerman, A. J., \& Cavalli-Sforza, L. L. (1984). The Neolithic transition and the genetics of populations in Europe. Princeton: Princeton Univesity Press.

Ascher, R. (1961). Analogy in archaeological interpretation. Southwestern Journal of Anthropology, 17, $317-325$.

Blench, R. (1993a). Ethnographic and linguistic evidence for the prehistory of African ruminant livestock, horses and ponies. In T. Shaw, P. J. J. Sinclair, B. Andah, \& A. Okpoko (Eds.), The archaeology of Africa: Food, metals and towns (pp. 71-103). London: Routledge.

Blench, R. (1993b). Recent developments in African language classification and their implications for prehistory. In T. Shaw, P. J. J. Sinclair, B. Andah, \& A. Okpoko (Eds.), The archaeology of Africa: Food, metals and towns (pp. 126-138). London: Routledge.

Blench, R. (2012). Two vanished African maritime traditions and a parallel from South America. African Archaeological Review, 29 (2/3).

Blench, R., \& MacDonald, K. (1999). The origins and development of African livestock: Archaeology, genetics, linguistics and ethnography. London: Routledge.

Bostoen, K. (2007). Pots, words and the Bantu problem: On lexical reconstruction and early African history. The Journal of African History, 48(2), 173-199.

Cann, R. L., Stoneking, M., \& Wilson, A. C. (1987). Mitochondrial DNA and human evolution. Nature, 325(6099), 31-36.

Cavalli-Sforza, L. L., Menozzi, P., \& Piazza, A. (1994). The history and geography of human genes. Princeton: Princeton University Press.

Collett, D. P. (1993). Metaphors and representations associated with precolonial iron-smelting in eastern and southern Africa. In T. Shaw, P. J. J. Sinclair, B. Andah, \& A. Okpoko (Eds.), The archaeology of Africa: Food, metals and towns (pp. 499-510). London: Routledge.

David, N., \& Kramer, C. (2001). Ethnoarchaeology in action. Cambridge: Cambridge University Press.

David, N., Sterner, J., \& Gavua, K. (1988). Why pots are decorated. Current Anthropology, 29(3), 365-389.

de Luna, K. (2012). Surveying the boundaries of historical linguistics and archaeology: Early settlement in South Central Africa. African Archaeological Review, 29(2/3).

Deguilloux, M.-F., Leahy, R., Pemonge, M.-H., \& Rottier, S. (2012). European neolithization and ancient DNA: An assessment. Evolutionary Anthropology, 21, 24-37.

Delius, P., \& Schoeman, M. (2010). Introduction. African Studies, 69(2), 207-212.

DeMarrais, E., Castillo, L., \& Earle, T. (1996). Ideology, materialization, and power strategies. Current Anthropology, 37, 15-31.

Dietler, M., \& Herbich, I. (1989). Tich Matek: The technology of Luo pottery production and the definition of ceramic style. World Archaeology, 21, 148-164.

Eggert, M. K. H. (1993). Central Africa and the archaeology of the equatorial rainforest: Reflections on some major topics. In T. Shaw, P. J. J. Sinclair, B. Andah, \& A. Okpoko (Eds.), The archaeology of Africa: Food, metals and towns (pp. 289-329). London: Routledge.

Ehret, C. (1993). Nilo-Saharans and the Saharo-Sudanese Neolithic. In T. Shaw, P. J. J. Sinclair, B. Andah, \& A. Okpoko (Eds.), The archaeology of Africa: Food, metals and towns (pp. 104-125). London: Routledge.

Ehret, C. (1998). An African Classical age. Charlottesville: University Press of Virginia.

Ehret, C. (2000). Testing the expectations of glottochronology against the correlations of language and archaeology in Africa. In C. Renfrew, A. McMahon, \& L. Trask (Eds.), Time depth in historical linguistics (pp. 373-399). Cambridge: MacDonald Institute for Archaeological Research.

Ehret, C. (2012). Linguistic archaeology. African Archaeological Review, 29(2/3).

Ehret, C., \& Posnansky, M. (Eds.). (1982). The archaeological and linguistic reconstruction of African history. Berkeley: University of California Press. 
Excoffier, L., Pellegrini, B., Sanchez-Mazas, A., Simon, C., \& Langaney, A. (1987). Genetics and history of sub-Saharan Africa. American Journal of Physical Anthropology, 30(S8), 151-194.

Fleisher, J., \& Wynne-Jones, S. (2012). Finding meaning in ancient Swahili spatial practices. African Archaeological Review, 29(2/3).

Flight, C. (1981). Trees and traps: Strategies for the classification of African languages and their historical significance. History in Africa, 8, 43-74.

Gonzales, R. M. (2009). Societies, religion, and history: Central-east Tanzanians and the world they created, c. 200 BCE to 1800 CE. New York: Columbia University Press.

Gramly, R. M. (1978). Expansion of Bantu-speakers versus development of Bantu language and African culture in situ: An archaeologist's perspective. South African Archaeological Bulletin, 33, 107-112.

Hall, M. (1990). Farmers, kings, and traders: The people of southern Africa, 200-1860. Chicago: University of Chicago Press.

Herbich, I. (1987). Learning patterns, potter interaction and ceramic style among the Luo of Kenya. The African Archaeological Review, 5, 193-204.

Hodder, I. (1982). Symbols in action. Cambridge: Cambridge University Press.

Horton, M. C., \& Middleton, J. (2000). The Swahili: The social landscape of a mercantile society. Oxford: Blackwell.

Inomata, T., \& Coben, L. S. (Eds.). (2006). Archaeology of performance: Theaters of power, community, and politics. Archaeology in society series. Lanham: Altamira Press.

Insoll, T. (2009). Materializing performance and ritual: Decoding the archaeology of movement in Tallensi shrines in northern Ghana. Material Religion: The Journal of Objects, Art and Belief, 5(3), 288-310.

Keita, S. O. Y. (2005). Physical anthropology and African history. In J. E. Philips (Ed.), Writing African history. Rochester: University of Rochester Press.

Kense, F. J., \& Okoro, J. A. (1993). Changing perspectives on traditional iron production in West Africa. In T. Shaw, P. J. J. Sinclair, B. Andah, \& A. Okpoko (Eds.), The archaeology of Africa: Food, metals and towns (pp. 449-458). London: Routledge.

Kiriama, H. (1993). The iron using communities in Kenya. In T. Shaw, P. J. J. Sinclair, B. Andah, \& A. Okpoko (Eds.), The archaeology of Africa: Food, metals and towns (pp. 484-498). London: Routledge.

Klieman, K. A. (2003). "The Pygmies were our compass": Bantu and Batwa in the history of West Central Africa, early times to c. 1900 C.E. Portsmouth: Heinemann.

Kuper, A., \& van Leynseele, P. (1978). Social anthropology and the "Bantu Expansion." Africa, 48, 335353.

Kusimba, C. M. (1999). The rise and fall of Swahili states. Walnut Creek: Altamira Press.

Livingstone, F. B. (1957). Sickling and malaria. British Medical Journal, 1(5021), 762-763.

Lucero, L. (2010). Materialized cosmology among ancient Maya commoners. Journal of Social Archaeology $10(1), 138-167$.

Lwanga-Lunyiigo, S. (1976). The Bantu problem reconsidered. Current Anthropology, 17, 282-286.

MacEachern, S. (2000). Genes, tribes, and African history. Current Anthropology, 41(3), 357-384.

MacEachern, S. (2012). The Holocene history of the southern Lake Chad Basin: Archaeological, linguistic and genetic evidence. African Archaeological Review, 29(2/3).

MacGaffey, W. (1978). African history, anthropology and the rationality of natives. History in Africa, 5, 103.

Marck, J., \& Bostoen, K. (2011). Proto-Oceanic (Austronesian) and Proto-East Bantu society (NigerCongo) residence, descent, and kin terms, ca. 1000 BC. In D. Jones \& B. Milicic (Eds.), Kinship, language, and prehistory: Per Hage and the renaissance in kinship studies. Salt Lake City: University of Utah Press.

McIntosh, S. K. (Ed.). (1999). Beyond chiefdoms: Pathways to complexity in Africa. Cambridge: Cambridge University Press.

McIntosh, S. K., \& McIntosh, R. J. (1980). Prehistoric investigations in the region of Jenne, Mali: A study in the development of urbanism in the Sahel. Oxford: B.A.R.

McIntosh, S. K., \& Scheinfeldt, L. (2012). It's getting better all the time: comparative perspectives from Oceania and West Africa on genetic analysis and archaeology. African Archaeological Review, 29(2/3).

Meskell, L. (Ed.). (2005). Archaeologies of materiality. Oxford: Blackwell.

Miller, D. (Ed.). (2005). Materiality. Durham: Duke University Press.

Mulaudzi, M., Schoeman, M. H., \& Chirikure, S. (2010). 500 year initiative. South African Historical Journal, 62(2), 219-286.

Nurse, D., \& Hinnebusch, T. J. (1993). Swahili and Sabaki: A linguistic history. Berkeley: University of California Press.

Nurse, D., \& Spear, T. (1985). The Swahili: Reconstructing the history and language of an African society $A D$ 800-1500. Philadelphia: University of Pennsylvania Press. 
Pakendorf, B., Bostoen, K., \& de Filippo, C. (2011). Molecular perspectives on the Bantu expansion: A synthesis. Language Dynamics and Change, 1(1), 50-88.

Phillipson, D. W. (1977). The later prehistory of eastern and southern Africa. London: Heinemann.

Phillipson, D. W. (1985). African archaeology. Cambridge: Cambridge University Press.

Phillipson, D. W. (1993). The antiquity of cultivation and herding in Ethiopia. In T. Shaw, P. J. J. Sinclair, B. Andah, \& A. Okpoko (Eds.), The archaeology of Africa: Food, metals and towns (pp. 344-358). London: Routledge.

Pikirayi, I. (2001). The Zimbabwe culture: Origins and decline of southern Zambezian states. Walnut Creek: Altamira Press.

Reid, R. (2011). Past and presentism: The "precolonial" and the foreshortening of African history. Journal of African History, 52, 135-155.

Robertshaw, P. (1999). Seeking and keeping power in Bunyoro-Kitara, Uganda. In S. K. McIntosh (Ed.), Beyond chiefdoms: Pathways to complexity in Africa (pp. 124-135). Cambridge: Cambridge University Press.

Robertshaw, P. (2000). Sibling rivalry?: The intersection of archaeology and history. History in Africa, 27, 261-286.

Robertshaw, P. (2010). Beyond the segmentary state: Creative and instrumental power in western Uganda. Journal of World Prehistory, 23, 255-269.

Robertshaw, P. (2012). African archaeology, multi-disciplinary reconstructions of Africa's recent past, and archaeology's role in future collaborative research. African Archaeological Review, 29(2/3).

Robertson, J. (1981). South central Africa. In D. I. Ray, P. L. Shinnie, \& D. Williams (Eds.), Into the 80's: Proceedings of the Eleventh Annual Conference of the Canadian Association of African Studies (pp. 86-98). Vancouver: Tantalus Research.

Robertson, J. \& Bradley, R. (2000). A new paradigm: The African Early Iron Age without Bantu migrations. History in Africa, 27, 287-323.

Rowlands, M. J., \& Warnier, J.-P. (1993). The magical production of iron in the Cameroon grassfields. In T. Shaw, P. Sinclair, B. Andah, \& A. Okpoko (Eds.), Archaeology of Africa: Food, metals, and towns (pp. 512-550). London: Routledge.

Saidi, C. (2010). Women's authority and society in early east-central Africa. Rochester: University of Rochester Press.

Sapir, E. (1985). Selected writings in language, culture, and personality. Berkeley: University of California Press.

Schmidt, P. R. (1978). Historical archaeology: A structural approach in an African culture. Westport: Greenwood Press.

Schmidt, P. R. (1983). An alternative to a strictly materialistic perspective: A review of historical archaeology, ethnoarchaeology, and symbolic approaches in African archaeology. American Antiquity, 48, 62-79.

Schmidt, P. R. (2006). Historical archaeology in Africa: Representation, social memory, and oral traditions. Lanham: Altamira Press.

Schmidt, P. R., \& Mapunda, B. (1997). Ideology and the archaeological record in Africa: Interpreting symbolism in iron smelting technology. Journal of Anthropological Archaeology, 16, 73-102.

Schoenbrun, D. L. (1998). A green place, a good place: Agrarian change, gender, and social identity in the Great Lakes region to the 15th century. Portsmouth: Heinemann.

Schoenbrun, D. L. (2012). Mixing, moving, making, meaning: Possible futures for the distant past. African Archaeological Review, 29(2/3).

Schrire, C. (1980). An inquiry into the evolutionary status and apparent identity of San hunter-gatherers. Human Ecology, 8, 9-32.

Shaw, T., Sinclair, P., et al. (Eds.). (1993). The archaeology of Africa: Food, metals and towns. London: Routledge.

Shetler, J. B. (2007). Imagining Serengeti: A history of landscape memory in Tanzania from earliest times to the present. Athens: Ohio University Press.

Soares, P., Achilli, A., Semino, O., Davies, W., Macaulay, V., Bandelt, H., Jr., \& Richards, M. B. (2010). The archaeogenetics of Europe. Current Biology, 20(4), R174-R183.

Soper, R. C. (1971). The Bantu Studies Project. Azania, 6, 1-4.

Spriggs, M. (2011). Archaeology and the Austronesian expansion: Where are we now? Antiquity, 85, 510-528.

Stahl, A. B. (1993). Concepts of time and approches to analogical reasoning in historical perspective. American Antiquity, 58(2), 235-260.

Stahl, A. B. (1994). Change and continuity in the Banda area, Ghana: The direct historical approach. Journal of Field Archaeology, 21, 181-203. 
Stahl, A. B. (2001). Making history in Banda: Anthropological visions of Africa's past. Cambridge: Cambridge University Press.

Stahl, A. B. (2005). African archaeology: A critical introduction. Malden: Blackwell.

Stahl, A. B. (2009). The archaeology of African history. International Journal of African Historical Studies, 42, 241-255.

Stahl, A. B. (2010). 'Route Work' through alternative archives: Reflections on cross-disciplinary practice. South African Historical Journal, 62(2), 252-267.

Stahl, A. B., \& LaViolette, A. (2009). Introduction: Current trends in the archaeology of African history. International Journal of African Historical Studies, 42(3), 347-350.

Stephens, R. (2009). Lineage and society in precolonial Uganda. Journal of African History, 50(2), 203221.

Stephens, R. (forthcoming). A history of African motherhood: The case of Uganda, 700-1900. Cambridge: Cambridge University Press.

Steward, J. (1942). The direct historical approach in archaeology. American Antiquity, 7, 337-343.

Swanepoel, N., Esterhuysen, A., \& Bonner, P.L. (Eds.). (2008). Five hundred years rediscovered: Southern African precedents and prospects. Johannesburg: Wits University Press.

Tishkoff, S. A., Reed, F. A., et al. (2009). The genetic structure and history of Africans and African Americans. Science, 324(5930), 1035-1044.

Vansina, J. (1979). Bantu in the crystal ball, part I. History in Africa, 6, 287-333.

Vansina, J. (1980). Bantu in the crystal ball, part II. History in Africa, 7, 293-325.

Vansina, J. (1990). Paths in the rainforests: Toward a history of political tradition in equatorial Africa. Madison: The University of Wisconsin Press.

Vansina, J. (1994/1995). A slow revolution: Farming in subequatorial Africa. Azania, 29/30, 15-26.

Vansina, J. (1995a). Historians, are archaeologists your siblings? History in Africa, 22, 369-408.

Vansina, J. (1995b). New linguistic evidence and the Bantu expansion. Journal of African History, 36, 173195.

Vansina, J. (2004). How societies are born: Governance in West Central Africa before 1600. Charlottesville: University of Virginia Press.

Vansina, J. (2009). Is a journal of method still necessary? History in Africa, 36, 421-438.

Veeramah, K. R. D., Zeitlyn, V. G., Fanso, N. R., Mendell, B. A., Connell, M. E., Weale, N. Bradman, \& Thomas, M. G. (2008). Sex-specific generic data supports one of two alternative versions of the foundation of the ruling dynasty of the Nso in Cameroon. Current Anthropology 49, 707-714.

Williamson, K. (1993). Linguistic evidence for the use of some tree and tuber food plants in southern Nigeria. In T. Shaw, P. J. J. Sinclair, B. Andah, \& A. Okpoko (Eds.), The archaeology of Africa: Food, metals and towns (pp. 139-153). London: Routledge.

Wilmsen, E., \& Denbow, J. (1990). Paradigmatic history of San-speaking peoples and current attempts at revision. Current Anthropology, 31(5), 489-524.

Wylie, A. (1985). The reaction against analogy. Advances in Archaeological Method and Theory, 8, 63111. 